\title{
1966-A Year of Challenge for Monetary Management
}

R APIDLY CHANGING economic conditions and demands on financial markets required great flexibility in implementing monetary policy in 1966. This need for flexibility led to several significant innovations in the Federal Reserve's conduct of open market operations. It also led to some new methods of employing regulations and other actions to complement open market operations.

The purpose of this article is to review important monetary developments during the year and to identify, interpret, and assess significant changes in the techniques of monetary management. To this end, major monetary actions are discussed. The new techniques are then treated in more detail. Most of these techniques have been introduced since last spring. Such limited experience in using them does not provide a sufficient basis for evaluating them empirically. This article, therefore, presents an assessment of their potential for monetary management.

The recently released Fifty-Third Annual Report of the Board of Governors of the Federal Reserve System, Covering Operations for the Year 1966 presents a comprehensive review of economic developments during the year and policy responses to these developments. The Report is the main source for this article, and it contains the current economic directives and continuing authority directives referred to later.

\section{Review of Federal Reserve Monetary Actions}

The Federal Reserve System's most flexible tool for influencing monetary and credit expansion or contraction is its ability to alter nember bank reserves by purchasing or selling Government securities. These actions, generally referred to as open market operations, are conducted by the Trading Desk of the Fed- eral Reserve Bank of New York under the direction of the Federal Open Market Committee (FOMC). ${ }^{1}$

The FOMC issues a "current economic policy directive" every three or four weeks. This directive serves as the Committee's formal statement of policy and provides operating instructions for the Trading Desk. In 1966 , as in preceding years, the directive contained three major points. The Committee:

(1) reviewed recent developments in economic and financial conditions relevant to the formulation of monetary policy,

(2) indicated broad goals for policy (such as high employment, sustainable economic growth, price stability, and a viable balance of payments), and specified intermediate objectives of monetary expansion to achieve these goals,

(3) instructed the Trading Desk to attain a prescribed set of money market conditions that would presumably lead to the desired movements in the intermediate objectives.

Exhibit I (pages 12 and 13) presents the current economic policy directive in effect at the beginning of 1966 and the directives adopted at the Committee's fifteen meetings during last year. This exhibit summarizes chronologically the Committee's view of economic and financial conditions in 1966 (Column 1), its policy decisions in response to these conditions (Column 2), and its operating instructions to the Trading Desk (Column 3).

\footnotetext{
1. The FOMCs voting membership consists of the seven members of the Bond of Governors, the President of the Federal Reserve Bank of New York, and the Presidents of four other Reserve Banks (on a rotating basis). The seven Reserve Bank Presidents who are not voting members in a given year do, however, attend the FOMC meetings and participate in the discussions.
} 


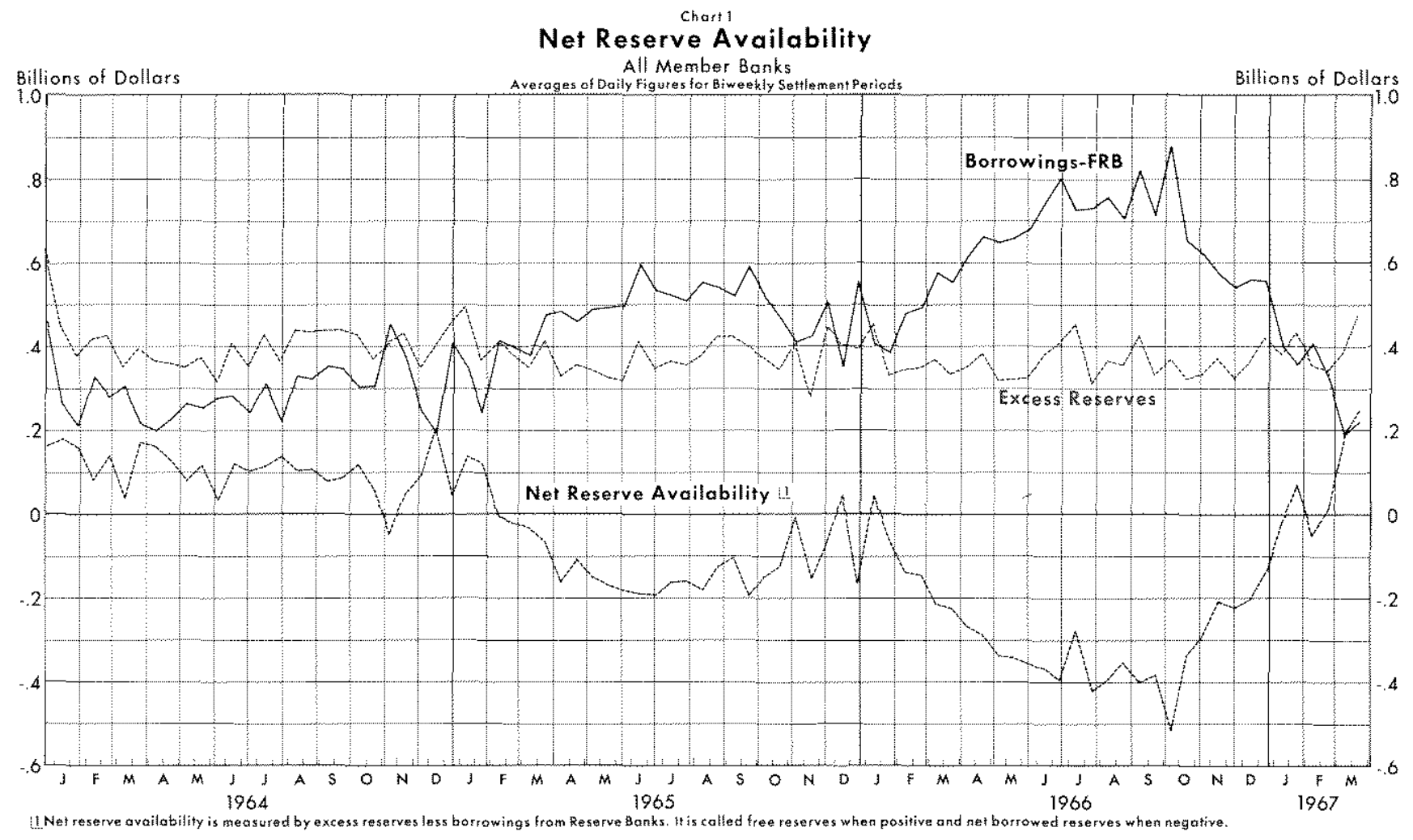

Exhibit II (page 20) summarizes other monetary actions taken by the Federal Reserve System during the year. These actions complemented the open market operations described in Exhibit I.

The impact of monetary actions in the short run is frequently meastred at two levels-changes in money market conditions and movements in aggregate monetary measures. These measures, however, also reflect fiscal actions and other economic and financial developments, making it difficult to isolate the effect of monetary actions alone.

The chief money market indicators considered in this article are net reserve availability of member banks (Chart 1), key money market interest rates (Chart 2), rates on large certificates of deposit (Chart 3), and capital market rates (Chart 4). Aggregate monetary measures considered are rates of expansion in total member bank reserves (Chart 5), money stock (Chart 6), money plus time deposits (Chart 7), and commercial bank credit (Chart 8 ).

An examination of the policy record for 1966 indicates that the year may appropriately be divided into three major periods. These periods are Jamuary through April, May through October, and November and December. Monetary developments in each period are reviewed in the next few pages.

\section{Janurry through Aprib- Desire for Pestraint}

From January through April, production was approaching capacity, spending was rising rapidly, and prices were spiraling upward. The FOMC directives called for increased monetary restraint. Money market conditions became tighter, but most aggregate monetary measures continued to expand at very rapid rates.

As the year began, goals of policy were "to complement other recent measures taken to resist the emerm gence of inflationary pressures and to help restore reasonable equilibrium in the country's balance of pay. ments." In December 1965, the Federal Reserve Board had raised the discount rate from 4 per cent to $4{ }^{3}$ per cent and the Regulation Q ceiling rate on time deposits from $4 \%$ per cent to $5 \%$ per cent. Open market operations were directed to moderate adjustments in the money market flowing from these actions.

The Committee continted to state the same broad goals at its first meeting in 1966 , but deleted the phrase "to complement other recent measures taken." The intermediate objective was changed from "accommodating moderate growth" to "moderating the growth" in the reserve base, bank credit, and the money supply (Exhibit I, Column 2). This was a slight move 


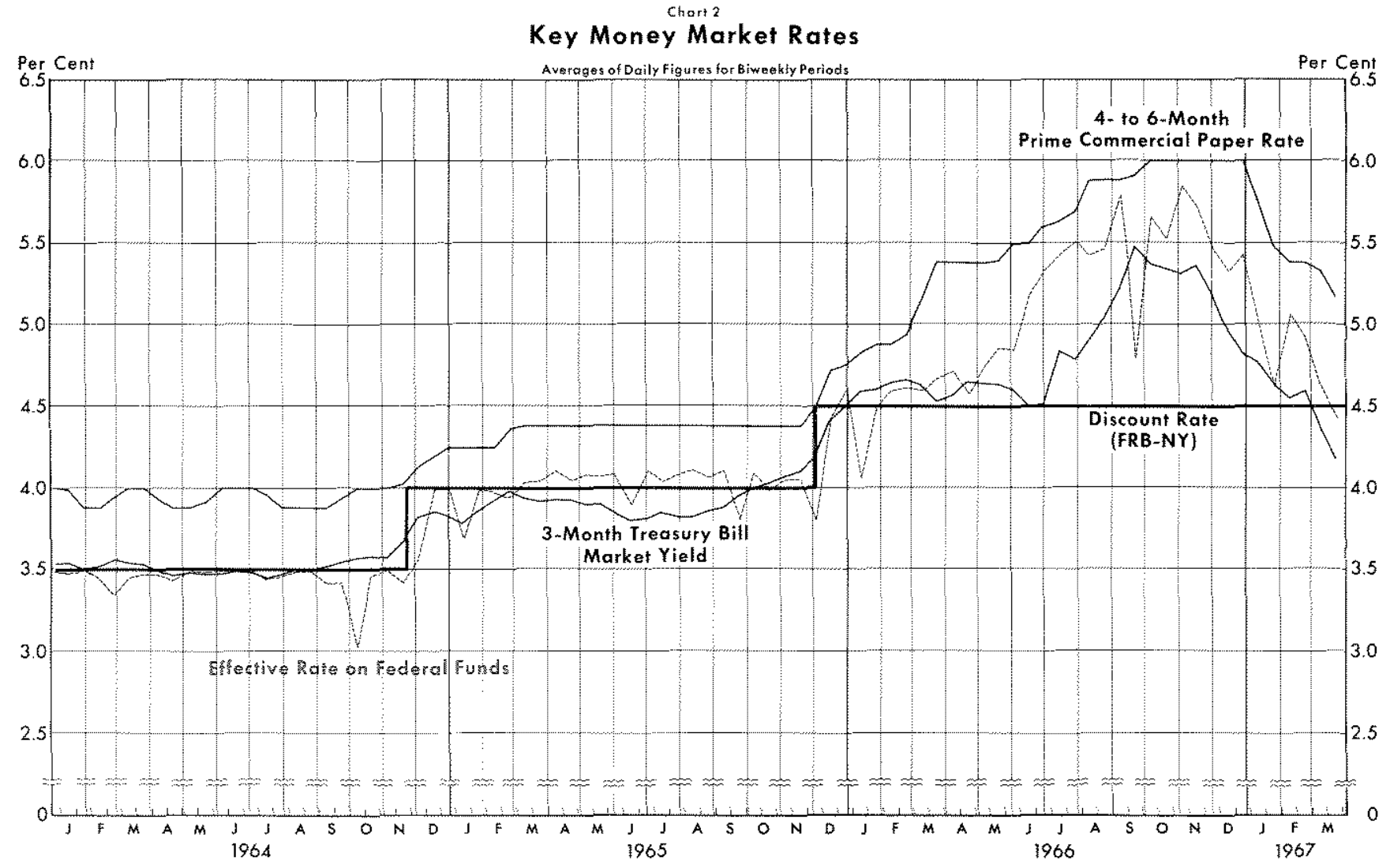

toward restraint. At the same time, existing money market conditions were to be maintained, chiefly because of the Treasury financing schedule (Exhibit I, Column 3). The broad goals and intermediate objectives of policy were not changed at the next meeting, but the operating instructions called for a move "toward a gradual reduction in reserve availability," still "with appropriate regard for the current Treasury financing." This was a further modest move toward restraint.

The Committee voted at its March I meeting to resist "inflationary pressures" rather than "the emergence" of such presstres. Instructions called for "some further gradual reduction in reserve availability." In April, the Committee changed its intermediate objectives to "restricting the growth in the reserve base, bank credit, and the money supply" rather than just "moderating" such growth.

Money market conditions tightened significantly from January to April. Net reserve availability had fallen to minus $\$ 250$ million by the end of the period (Chart 1). This contrasted with an almost balanced net reserve position in December and January (when the System was accommodating adjustments to the discount rate increase) and was about $\$ 100$ million lower than average net reserve availability during the latter months of 1965 .

Most market interest rates rose from December to April, indicating firmer market conditions (Chart 2). The three-month Treasury bill rate and the effective rate on Federal funds were slightly above the discount rate. Offering rates on large certificates of deposit had risen sharply, following the change in the Regulation $Q$ ceiling rate which had previously prevented further increases (Chart 3). Capital market rates, which frequently respond slowly to changing market conditions, rose significantly (Chart 4 ),

While money market conditions became markedly tighter, most aggregate monetary measures continued to expand rapidly. Total member bank reserves and money each increased at an annual rate of almost 7 per cent from December to April (Charts 5 and 6). Money plus time deposits increased at an 8 per cent rate, and bank credit increased at a 9 per cent rate (Charts 7 and 8). Each of these rates was high by historical standards.

Aggregate monetary measures increased rapidly, while money market conditions tightened significantly; this fact suggests that rapidly rising economic activity in early 1966 and its accompanying great demand for credit from both the private and public sectors were 


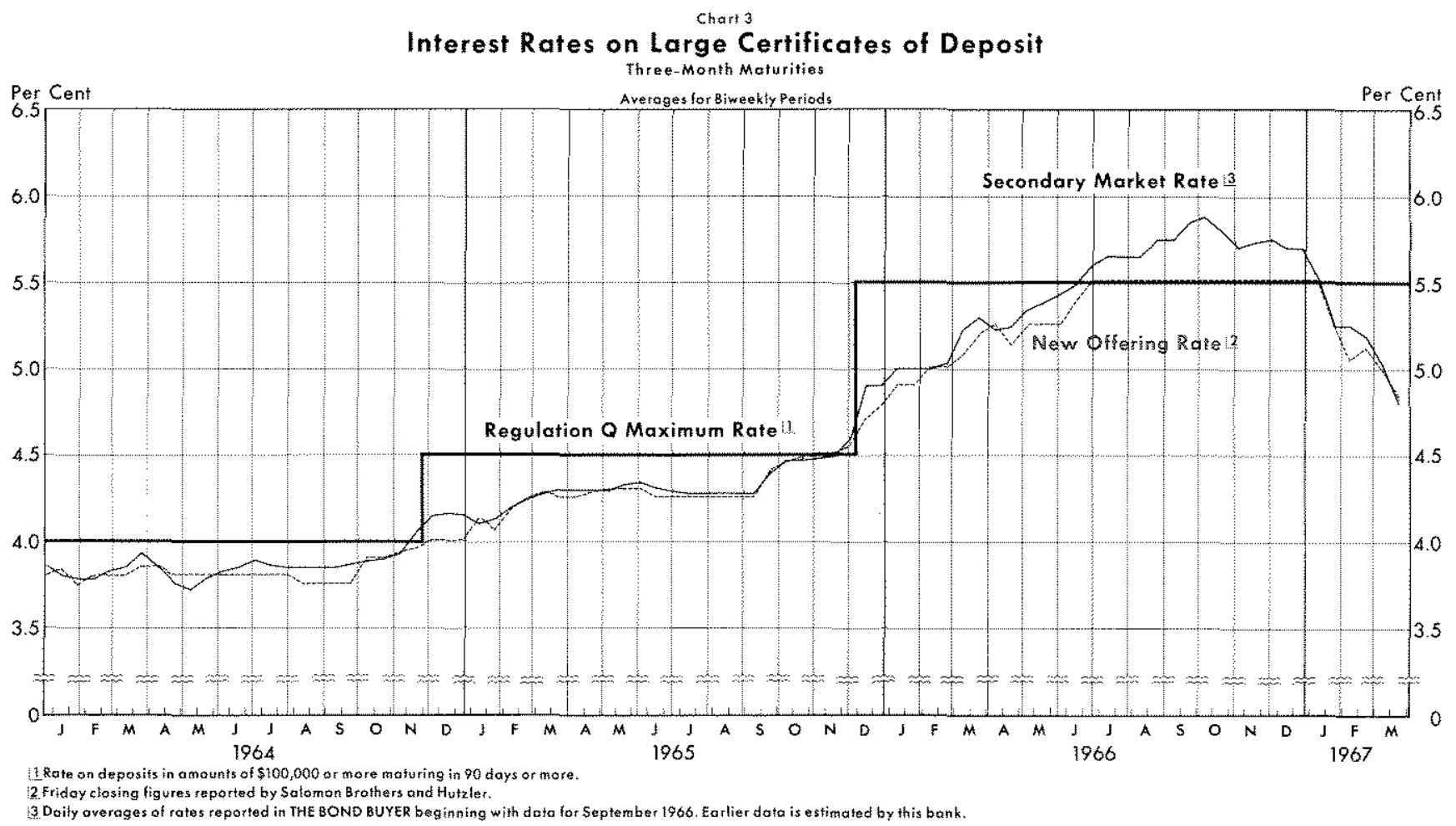

the main cause of money market tightening. In response to these economic forces, interest rates and member bank borrowing from the Federal Reserve rose significantly. System actions, in retrospect, were not sufficiently restrictive to stem the rapidly expanding loan demand, and monetary aggregates rose sharply. These actions, however, were taken at a time when public opinion was concerned about rising interest rates, and monetary policy was generally criticized for being too restrictive-not too expansionary.

\section{Wry hrongh Oetoberw Eflerive Prestrant}

Total demand for goods and services continued to exceed available supply from May through October. Policy was more aggressively directed toward restraining total demand; it called for restricting growth in the aggregate monetary measures. The System employed several innovations to help implement its policy within the context of a rapidly changing economic situation. During this period, measures of aggregate monetary variables moved more consistently with the desires of the Committee than they had earlier in the year.

The directive adopted at the May 10 meeting altered the broad goals of policy only slightly, but it included a significant change in the operating instructions-the introduction of the "proviso clause." This clause modified the instruction for "attaining some further grad- ual reduction in net reserve availability" by calling for "a greater reduction if growth in required reserves does not moderate substantially." The proviso clause represents one of the most important innovations of the year and is discussed further in a later section of this article. Each subsequent directive during the year included a modifying clause of this type (itali cized clauses in Exhibit I, Column 3).

The directives adopted at the next several meetings made no change in the broad goals of policy. The June 7 version called for maintaining recent money market conditions unless required reserves expanded considerably more than expected. In such a case, the manager was directed to seek a further firming in market conditions. The expected movements mentioned in the proviso clause referred to projections made by the Committee's staff for presentation at each FOMC meeting and updated between meetings.

On June 27, the Federal Reserve Board introduced for the first time differential reserve requirements by class of time deposits. The Board announced that reserve requirements on certificates and most other forms of time deposits in excess of $\$ 5$ million at each member bank wotld be raised from 4 per cent to 5 per cent in July (Exhibit II). Reserve requirements on savings deposits and the first $\$ 5$ million of time deposits were left at 4 per cent. Introduction of the differential was prompted in part by the aggressiveness of banks in 
Exhibit I

FEDERAL OPEN MARKET COMMITTEE CURRENT ECONOMIC POLICY DIRECTIVES

(1)

\begin{tabular}{|c|c|}
\hline $\begin{array}{l}1966 \\
\text { Jan. } 11\end{array}$ & 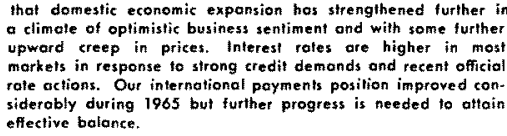 \\
\hline Feb. 8 & $\begin{array}{l}\text { that the domestit economy is expanding vigorously, with prices } \\
\text { continuing to creep up and credit demands remaining strong. } \\
\text { Our inlernational poyments continue in deficit. }\end{array}$ \\
\hline
\end{tabular}

\begin{tabular}{|c|c|c|}
\hline Mar. 1 & same as above & $\begin{array}{l}\text { to resist inflationary pressures and to help } \\
\text { restore reasonable equilibrium in the counlry's } \\
\text { bolance of poyments, by moderating the } \\
\text { growth in the reserve base, bonk eredit, ond } \\
\text { the money supply. }\end{array}$ \\
\hline Mar. 22 & same os above & some as above \\
\hline Apr. 12 & $\begin{array}{l}\text { that the domestic exonomy is expanding vigorously, with in- } \\
\text { dustrial prices continuing to creep up and credit demands re. } \\
\text { maining strong. Our internationol payments continue in deficil. }\end{array}$ & $\begin{array}{l}\text { to resist infotionary pressures and to help } \\
\text { restore reasonable equitibriurm in the counlry's } \\
\text { bolance of payments, by restricling the growth } \\
\text { in the reserve base, bonk credit, and the } \\
\text { money supply. }\end{array}$ \\
\hline May 10 & $\begin{array}{l}\text { that the domestic economy is expanding vigotously, with in- } \\
\text { dustrial prices continuing to rise and credil demands remaining } \\
\text { strong. Our international poyments continue in deficit. }\end{array}$ & $\begin{array}{l}\text { Io resist inflationary pressures and to strength- } \\
\text { on efforts to restore teasonable equilibrium } \\
\text { in the country's bolance of payments, by re- } \\
\text { stricting the growth in the reserve base, bank } \\
\text { credit, and the meney supply. }\end{array}$ \\
\hline June 7 & 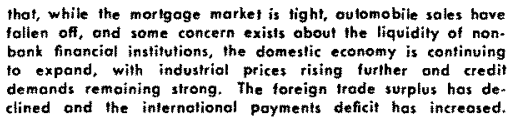 & some as above \\
\hline June 28 & 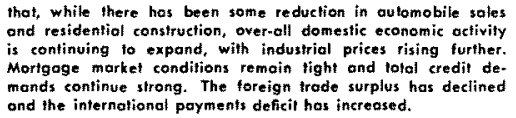 & some as above \\
\hline
\end{tabular}

Broad Goals and Intermediate Objectives of Monetary Policy In this situation, ${ }^{1}$ in is the Federal Open Market Committee's policy*

to complement other recent measures token to resis the emergence of inflationary pressures and to help restore reosonable equilibrium in the country's baiance of payments, while acbase, bank credit, and the money supply.

to resist the emergence of innationary pressures and to help restore reasonable equitibrium in the county's balonce of poyments, by bonk eredit, and the money supply.

ame os obove

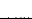

\begin{tabular}{|c|c|}
\hline $\begin{array}{l}\text { Dote of } \\
\text { FOMC } \\
\text { Meeting }\end{array}$ & Economic and Financial Conditions \\
\hline & $\begin{array}{l}\text { The economic and finansial dovelopments reviewed } \\
\text { of this meeting indicate }\end{array}$ \\
\hline $\begin{array}{l}1965 \\
\text { Dec. } 14\end{array}$ & $\begin{array}{l}\text { that domestic economic exponsion is goining in strength in a } \\
\text { climate of optimistic business sentiment, with contining octive } \\
\text { demands for credit and some further ypword creep in prices. } \\
\text { Although there appears to hove been some recent imptovement } \\
\text { in our internotional payments, the need for further progress } \\
\text { remeins. }\end{array}$ \\
\hline
\end{tabular}

Instructions to the Federal Reserve Bank of New York

(Proviso clouse in Itclics)

Until the next meeling of the Committee, and taking
into occount the forthcoming Irecsury financing octivity into account the forthcoming Irecsury financing octivity ond widely Auctuating seasonal pressures an in Reserve Benk discount rotes, System open morket operations sholl be directed to moderoting ony further adiustments in

In light of the Treasury financing schedule, System open market operations until the next meeting of the
Committee sholl be conducted with a view to mointaining about the current conditions in the money morket.

(2)

To implement this policy, $8,4,5$, system open
morket operations until the next meeting of the
Commlttee" shall be sonducted with o view"
",with appropriate regord for the current
ireosury financing. toward o gradual reduction in reserve aroilability.

to afloining some further grodual reduction in reserve same as above

10 oltaining some further grodual reduction in teserve availability, while taking into account the fortheoming

"while taking into account the current Treasury

to ottoining some further graducl reduction in net reserve availability, and a greater reduction if growth in re.
quired resertes does not moderate substantially. to maintaining net reserve ovailobility and reloted money market conditions in about theit recent ronges; prozided, bowever, that if required reserves expand consider.
ably more than seasonally expected, operations sball be comdurted with a view to attaining some furtber gradsul teduction in net reserve
frming of money market conditions.

to mointaining about the current state of net reserve availobitity and related money market conditions, excep as changes may be needed to moderate unusual liavidity that if sucb liguidity presstares are not wh ally strong and required peserve increases are larger than expected, onevations shall be conducted with
at vieu to attaining some furtber gradual reduction at vieu to attaining some further gradual reduction
in net reserte atailability and firming of “- mey
markel conditions.

\begin{tabular}{|c|c|c|c|}
\hline July 28 & 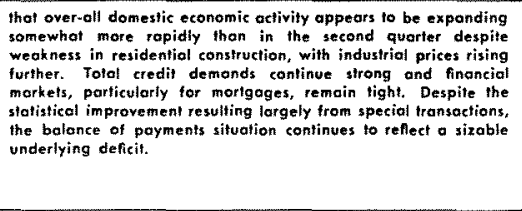 & some as obove & 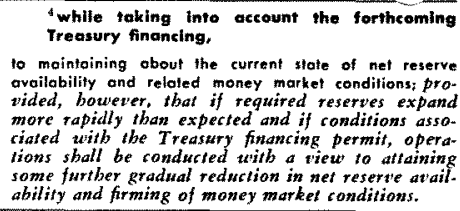 \\
\hline Aug. 23 & 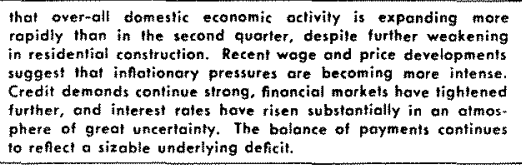 & some as obove & 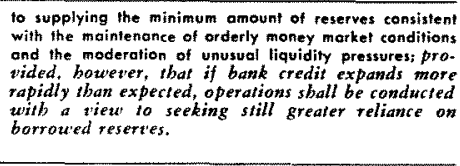 \\
\hline Sept. 13 & 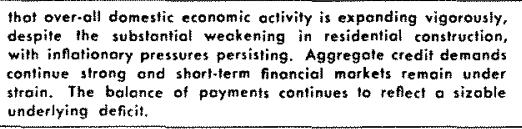 & $\begin{array}{l}\text { iand in light of the new fiscal } \\
\text { program announced by the President, } \\
\text { to resist inflationary pressures and to strength. } \\
\text { en efforts to restore reconable equilibrium } \\
\text { in the country's bolance of payments. }\end{array}$ & $\begin{array}{l}\text { to maintoining firm but ordefiy condifions in the money } \\
\text { market: provided, boweyer, that operations shall be } \\
\text { modified in the light of wnusual liquidity pressures } \\
\text { or of any opparently significant detiations of bank } \\
\text { credit from current expectations. }\end{array}$ \\
\hline Oet. 4 & $\begin{array}{l}\text { that over-all domestic economic octivity is exponding vigorously, } \\
\text { despite the substontifal weakening in residentiol construction, } \\
\text { uncertainties in equity markets, and o shorp increase in business } \\
\text { inventories. Inflationory pressures ore persisting and aggregate } \\
\text { credit demonds still remain strong. The balonse of poyments } \\
\text { continues to show a sirable liquidity deficit. }\end{array}$ & $\begin{array}{l}\text { xand in llght of the new fiscal } \\
\text { program announced by the President, } \\
\text { to resist infationary pressures and to continue } \\
\text { efforts to restore reasonoble equilibrium in the } \\
\text { country's bolance of payments. }\end{array}$ & $\begin{array}{l}\text { "and toking account of forthcoming Treosury } \\
\text { financings. } \\
\text { some as above }\end{array}$ \\
\hline Nov. 1 & 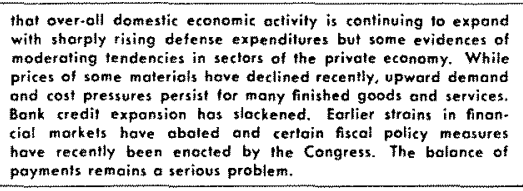 & $\begin{array}{l}\text { 10 mainlain money and credit conditions con. } \\
\text { ducive to the restroint of infationary pressures } \\
\text { and progress toward reasonoble equilibrium } \\
\text { in the country's bolance of payments. }\end{array}$ & 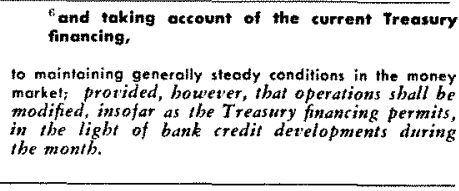 \\
\hline Nov. 22 & 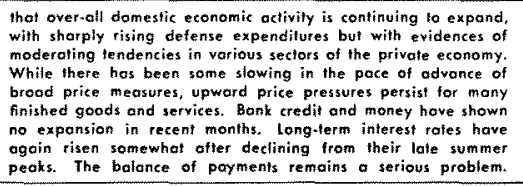 & $\begin{array}{l}\text { to maintain money and credit conditions con- } \\
\text { ducive to noninfiationary exonomic expansion } \\
\text { and progress foword reasonable equilibrium } \\
\text { in the country's balance of poyments. }\end{array}$ & $\begin{array}{l}\text { to allaining somewhat easier conditions in the money } \\
\text { market, woless bank rredit appears to be resuming } \\
\text { a rapid rate of expansion. }\end{array}$ \\
\hline Dec. 13 & $\begin{array}{l}\text { that over-all domestic economic artivity is continuing to expand, } \\
\text { with rising defense expenditures but with odditional evidences } \\
\text { of moderating lendencies in the privale economy. While there } \\
\text { has been some slowing in the poce of odvance of most brood } \\
\text { price measures, upward price pressures persist for mony finished }\end{array}$ & $\begin{array}{l}\text { 10 toster money and credit condifions condu- } \\
\text { cive to noninfationary economic exponsion ond } \\
\text { progress toward reasonable equilibrivm in the } \\
\text { country's balance of payments. }\end{array}$ & same os above \\
\hline
\end{tabular}
price measures, upward price pressures persist for mony finished
goods and services. Bonk credil and money hove shown no net exponsion in recent months. Although demands on bond markels have increased, upward pressures on long-term interest rates have moderc 
seeking new time deposits. Banks competed for these funds in order to meet rising loan demands without further reducing their liquidity positions. Because of increased competition from commercial banks, there was some concern that savings and loan associations might have large run-offs in their savings accounts after their midsummer dividend dates. Such run-offs would put further pressure on mortgage markets, which had already become extremely tight. The increase in reserve requirements was designed to moderate competition from commercial banks and thereby reduce potential run-offs at savings and loan associations and mutual savings banks.

Both business and Government demands for credit were increasing rapidly in early summer. Capital markets had been deluged with new issues. These circumstances, in addition to the pressure on savings institutions, led to the inclusion in the June 28 directive of a provision for changes in net reserve availability and market conditions "needed to moderate untsual liquidity pressures at financial institutions." Restraint was to be exercised, but orderly market conditions were to be maintained.

The Federal Reserve Board announced on August 17 that reserve requirements for time deposits in excess of $\$ 5$ million at each member bank would be raised further to a level of 6 per cent in September. This increased the differential in requirements by type of time deposit.

The August 23 directive reflected mounting strain in the financial markets, citing the "maintenance of orderly money market conditions and the moderation of unusual liquidity pressures" as a constraint on operations. Beginning with this directive, bank credit replaced required reserves as the operating guide specified in the proviso clause. The reserve base, bank credit, and the money supply were still cited as intermediate objectives.

The Presidents of the Federal Reserve Banks sent a letter to each member bank on September 1 regard. ing the administration of the discount facilities. This letter requested the banks to restrict expansion of their business loans and to avoid "dumping" their municipal security holdings (Exhibit II). It also offered assistance in financing current security holdings through use of the discount window. This was intended to help curb inflationary pressures financed by bank credit and to contribute to more orderly market conditions. At the time, there was a great deal of concem for the viability of the money and credit markets. Problems of meeting huge current and prospective credit demands in a dimate of System restraining actions were the chief cause of such concern.
Other branches of the Federal Government also took action in early September that helped to stabilize the economy and to moderate the upward trend in interest rates. The tax credit for business investment was suspended, and provisions for accelenated depreciation were curtailed. Steps were taken to reduce the impact of Federal agency financing on the eredit markets.

The FOMC's September 13 directive cited the new fiscal program as a major factor influencing monetary policy. The phrase "by restricting the growth in the reserve base, bank credit, and the money supply" was deleted from the statement of policy. Bank credit, the operating guide in the proviso clause, thus became the only aggregate monetary measure mentioned in the directive. The operating instructions called for "mainm taining firm but orderly conditions in the money market; provided, however, that operations shall be modified in the light of unusual liquidity pressures or of any apparently significant deviations of bank credit from current expectations." The same instructions were repeated in the October 4 directive. At both of these meetings, some of the Committee members favored relaxing slightly the degree of restraint. No formal change in policy was made, but significant deviations in bark credit mentioned in the proviso clause referred to slower growth than expected as well as to more rapid growth.

On September 26 , following the passage of enabling legislation, the Federal Reserve Board reduced the ceiling rate on time deposits of less than $\$ 100,000$ to 5 per cent (Exhibit II). Similar actions applying to financial institutions under their respective jurisdictions were taken by the Federal Deposit Insurance Corporation and the Federal Home Loan Bank Board.

Money market conditions and changes in the rates of monetary expansion both indicate that a considerable measure of restraint developed in the May to October period. Net reserve availability was generally in the lower range established in late spring (Chart 1). Most interest rates rose at a faster pace than in the preceding period with many reaching their highest levels in forty years. Federal funds and Treasury bills traded well above the discount rate during most of the period (Chart 2). Large certificates of deposit were offered at the $5 \%$ per cent ceiling rate, and the secondary market rate on these deposits rose considerably above the ceiling rate (Chart 3 ). Capital market rates also rose sharply as large issues competed for limited funds (Chart 4).

During the period there were substantial changes from the general practices of administering the discount rate and ceiling rates on time deposits. The discount rate has usually been changed whenever mar- 


\section{Capital Market Rates}

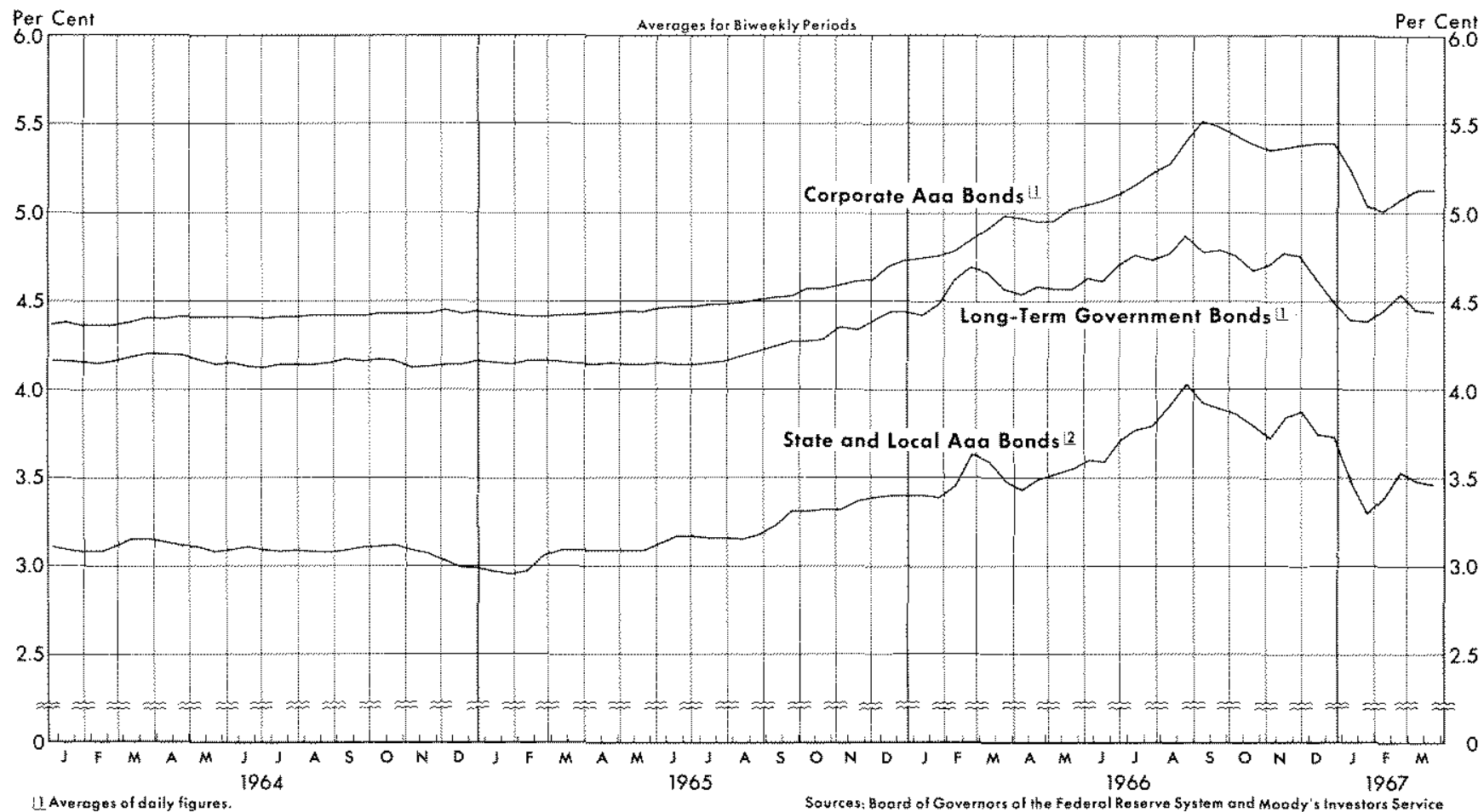

2 Areroges of Thu

ket rates were considerably above or below it. By mid-1966, the discount rate was out of contact with most market rates, and this situation persisted for several months. Furthermore, this period marked one of the few times that the ceiling rate allowed on time deposits was not raised when offering rates on these deposits were at the ceiling for a prolonged time. It was the first time that the rate ceiling led to a significant reduction in the volume of large negotiable certificates of deposit outstanding since these deposits became such an important source of funds for commercial banks.

The rates of monetary expansion showed the effect of restrictive monetary policy (Charts $5,6,7,8$ ). From April to October, total reserves declined at a 2.3 per cent annual rate, and money declined at a 1.5 per cent rate. Money plus time deposits increased at only a 2.6 per cent rate, and bank credit growth slowed to a 5.3 per cent rate. The sharp contraction in the volume of certificates of deposit outstanding was an important factor contributing to the slower rates of expansion of total deposits and bank credit.

During this period, the Federal Reserve reduced markedly the rate at which it was supplying fonds to the market. The System was not accommodating the great demand for funds to the extent it had earlier in the year. As a result, interest rates rose sharply, and rates of monetary expansion declined abruptly.

\section{November and December- Desire for Ease}

Late in 1966 , as the economic expansion appeared to be slowing, the Federal Open Market Committee stated a somewhat easier policy. Monetary restraint in the previous period, as indicated by lack of growth in bank reserves and money, slower growth in bank credit, and markedly higher interest rates, had helped curtail the excessive demand for goods and services.

Bank credit had not increased during October, in contrast to earlier expectations and Committee desires for some expansion. Following instructions in the proviso clanse of the October 4 directive, the Desk permitted somewhat less firm market conditions to develop prior to the November 1 FOMC meeting. At that meeting the Committee voted to relax slightly the degree of restraint. Policy was "to maintain money and credit conditions conducive to the restraint of inflationary pressures and progress toward reasonable equilibrim in the comtry's balance of payments." The operating instructions shifted emphasis from "maintaining firm but orderly conditions in the money market. . ." to "maintaining generally steady conditions in the money market; provided, however, that operations shall be modified. . . in the light of bank credit developments during the month."

The next two directives provided more overt moves 


\section{Reserves of Member Banks}

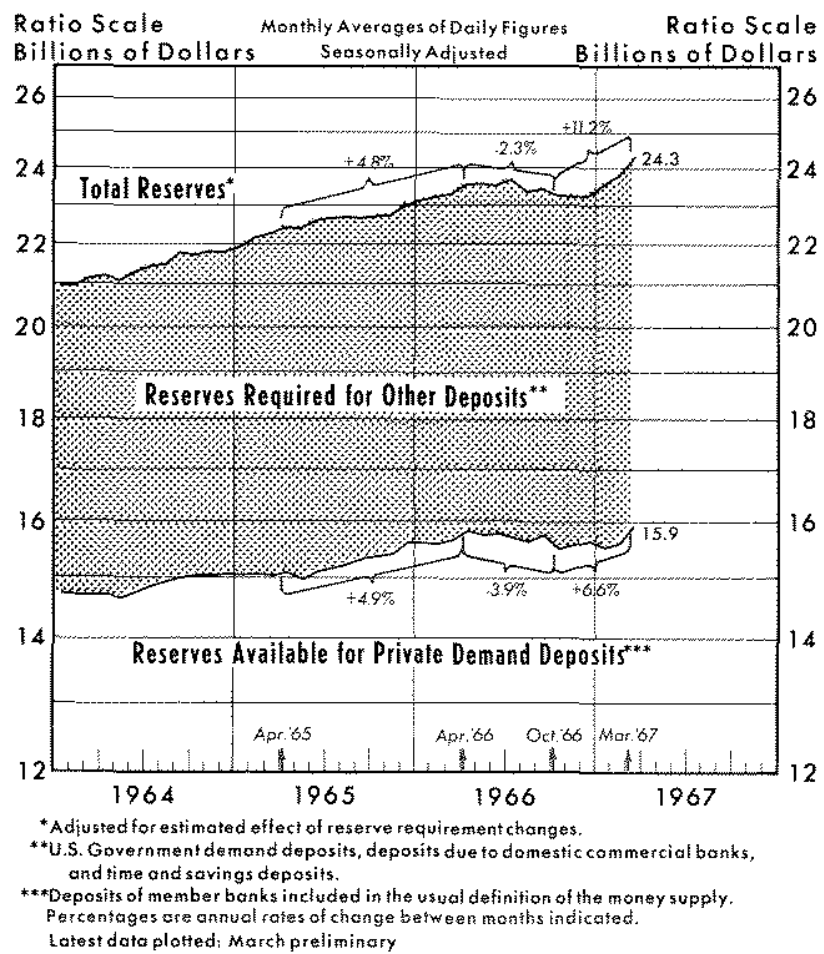

toward less restraint. The broad goals of policy, to "maintain" and then to "foster money and credit conditions conducive to noninflationary economic expansion," were to be achieved by "attaining somewhat easier conditions in the money market, unless bank credit appears to be resuming a rapid rate of expansion."

On December 27, the Presidents of the Federal Reserve Banks rescinded the September 1 letter. Its provisions were no longer deemed applicable because of changes in economic and financial conditions.

During late 1966 and early 1967, money market conditions became easier. Most rates of monetary expansion showed little change by the end of the year, but rose significantly in the first few months of 1967 . Net reserve availability increased as member bank borrowings from the Federal Reserve declined to the level of early 1966 and fell even lower in early 1967 (Chart 1). Money market rates dropped from their peaks, but remained at high levels by most past standards (Chart 2). Rates on certificates of deposit fell below the ceiling, and commercial banks were again able to attract these funds (Chart 3). Capital market rates declined only slightly in December, but went down more significantly in early 1967 (Chart 4).

Only a slight easing response in aggregate monetary measures was evident by the year's end (Charts 5,6 , $7,8)$. Total reserves and money responded slowly to the change in policy. Bank credit started to expand, but at first this reflected almost solely growth in time deposits. This renewed intermediation of banks was facilitated by declines in market rates not subject to regulation, enabling banks to compete more effectively for certificates of deposit. To some extent, such growth in time deposits and bank credit represented a rechanneling of funds through the banking system rather than a net expansion of funds to borrowers.

Rates of monetary expansion showed a significant acceleration in early 1967. This may represent a shorter lag between the time the Committee states a desire for change in the rates of expansion of aggregate monetary measures and the time when such changes actually appear in the measures. This implementation lag was probably shorter in late 1966 than in most previous periods, but still leaves room for improvement.

\section{Methods of Monetary Management}

The foregoing review of monetary developments during 1966 and early 1967 has pointed out several significant innovations in policy implementation. The new techniques may be divided into two categories: those related to open market operations and those involving complementary actions. This section discusses the new techniques and sets forth an assessment of each.

\section{Inrowations in Open Mraret Operations}

\section{Economic and Financial Conditions Specified More Clearly in the Directives}

Beginning in mid-1966, the directive became more specific in identifying the economic and financial conditions the Committee considered in formulating policy. The wording of the first part of the directive, which cites these conditions (Exhibit I, Column 1), was changed substantially at many of the meetings. By comparison, directives earlier in the year and in previous years contained less detailed descriptions of economic and financial conditions. These descriptions were modified more frequently in 1966 than in most previous years, reflecting in part the rapid pace at which economic conditions were changing.

Beginning with the June 7 directive, specific mention was made of such factors as the liquidity of nonbank financial institutions, conditions in the mortgage markets, and declining automobile sales. Later directives

2For excerpts from the FOMC current economic policy directives issued in 1965, see this Review, June 1966, pp. 8-9. 
added weakening in residential construction, increased strain in the financial markets, and rising business inventories. The September 13 directive cited "the new fiscal program announced by the President" as a factor influencing monetary policy. The November 1 directive observed that "certain fiscal policy measures have recently been enacted by the Congress." The Committee also noted that rising defense expenditures were becoming a larger factor in the continued expansion of economic activity.

The more complete summaries of economic and financial conditions in the directives provide the public with a concise record of those developments which the Committee considered most important. From this standpoint alone they are a valuable contribution. More importantly, these summaries focus the attention of the Committee and the Desk on the major issues concerning the nation's economic progress, as well as on the day-to-day problems of influencing money market conditions.

\section{Proviso Clause Introduced and Developed}

The introduction of the proviso clause was a most significant step forward in monetary management. This clause focuses on the linkage between money market conditions and movements in aggregate monetary measures - a linkage that needs to be more fully understood and more frequently considered in monetary management.

The proviso clause generally stated that open market operations between FOMC meetings were to be based on a prescribed set of money market conditions, provided that a specified aggregate monetary measure behaved in a particular way. If the operating guide did not behave as expected, the Desk was to effect appropriate changes in money market conditions. Previously, the Committee had stated its desired objectives for monetary and credit expansion in general terms but gave its instructions to the Desk only in terms of money market conditions. ${ }^{3}$

The clause was introduced on May 10, following a prolonged period when money and bank credit had expanded rapidly (contrary to FOMC desires) even though money market conditions had become progressively tighter (as the Committee had instructed). As pointed out previously, growing credit demands led to rapid monetary expansion even though market conditions tightened. Such results highlight the difficulty

\footnotetext{
3"The Strategy of Open Market Operations," by Jack Guttentag in the February 1966 Quarterly Journal of Econamics constructively criticizes the use of money market conditions alone as a guide for monetary policy. It proposes the use of various guides having different control periods.
}

of projecting a consistent relationship between money market conditions and aggregate monetary measures.

In retrospect, policy may have moved to restrain growth in monetary aggregates at too slow a pace from January to April, probably because of the concentration on money market conditions. The System supplied reserves to prevent even tighter market conditions from developing in response to sharply rising credit demands. Such actions led to rapid expansion in reserves and resulted in larger growth rates of money and bank credit than were desirable for the inflationary economic situation of early last year. These actions prevented interest rates from rising as sharply as economic forces at the time would otherwise have dictated.

The proviso clause was designed to help achieve desired changes in monetary aggregates at a time of rapidly changing demands for credit. It supplies a means for adjusting open market operations more swiftly to shifts in the linkages between money market conditions and aggregate monetary variables which result from changes in economic activity and expectations. In the past, the FOMC usually changed its instructions to the Desk regarding money market conditions at its periodic meetings- a rather slow process of trial and error during periods of rapid economic change. The proviso clause, in contrast, instructs the Desk Manager to change desired money market conditions between meetings. It directs him to alter the money market guide if new information indicates that the intermediate operating guide is not behaving in the desired manner. The provisions of the clause specify Committee desires more clearly over a broader range of measures, permitting changes in the short-run measures between meetings.

The proviso clause itself went through several changes during the year. The operating guide cited in the clause from May through mid-August was required reserves. In the following months it was bank eredit.

A new measure, the bank credit proxy, was developed during the year in order to get current information about the operating guide more frequently. This measure infers changes in member bank loans and investments (assets) from changes in member bank deposits (liabilities). ${ }^{4}$ Deposit data are available weekly on a daily average basis, whereas bank credit data are available less frequently.

\footnotetext{
t The October 1966 Fecleral Reserve Bulletin presents a monthly series on total deposits subject to reserves and on pages 1460 . 61 discusses the use and limitations of this series as a proxy for bank credit.
} 


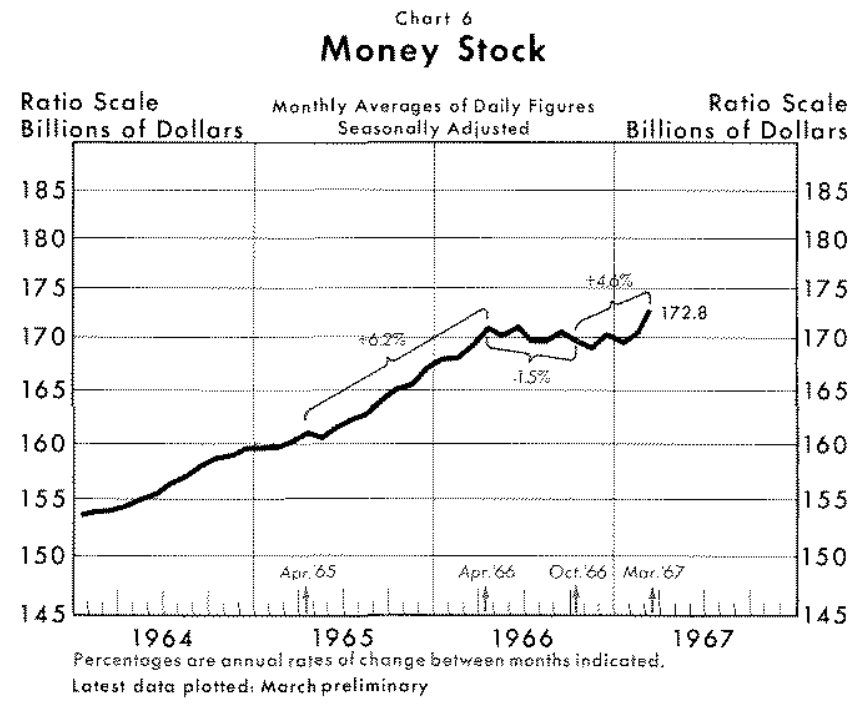

At times during the year the Committee altered the direction of change in the operating guide of the proviso clause. From May through August the clause was used to effect firmer market conditions if the operating guide expanded more rapidly than desired. By contrast, the September 13 and October 4 directives called for operations to be "modified in the light of ... any apparently significant deviations of bank credit from current expectations," as the Committee sought to resist a major change in either direction. Instructions in the November 1 directive were to be modified "in light of bank credit developments during the month," a double-edged proviso. On November 22 , the Committee decided on a less restrictive policy, ". . . attaining somewhat easier conditions in the money market, unless bank credit appears to be resuming a rapid rate of expansion." During the rest of the year, the clause was used as a safety valve to insure that the pace of monetary expansion did not exceed the Committee's desire.

Because the proviso clause is still too new to evalu" ate its actual effectiveness, this discussion deals mostly with its potential. The clause acknowledges formally that gradual and infrequent changes in money market conditions may not always result in desired movements in the aggregate measures. Therefore, it directs the Desk Manager to consider the most recent developments in the specified aggregate measure when interpreting his instructions concerning desired money market conditions.

Effective use of the proviso clause might help to prevent another situation like the one in 1960-61. At that time, money market conditions became easier, following Committee instructions, but the reserve base and money stock continued to decline for several months, contrary to FOMC desires. In retrospect, this happened because the economy was sliding into a recession, which by itself caused easier money market conditions. By focusing on the pace of market changes every three or four weeks and by not permitting more rapid changes in market conditions, System actions resulted in an undesired contraction of bank reserves and the money stock.

Use of the clause is an improvement over former practices because it provides the Desk with a specific rule for modifying the desired market conditions stated in the directive. One aggregate monetary measure is selected as an operating guide; its behavior then determines for the Desk when and how desired market conditions should be changed. ${ }^{5}$

In the past, several aggregate measures were mentioned as intermediate objectives, but they often behaved differently in the short run. This ambiguity made it difficult for the FOMC, the Desk, and the public to decide whether the specific intermediate goals of policy were being met.

Selecting one intermediate measure as an operating guide reduces this problem, but intensifes the importance of selecting the most appropriate one. Presumably, with perfect knowledge of all the interrelationships among financial and real variables, any broad measure which can be controlled by the monetary authorities would be as useful as any other. However, our knowledge of these interrelationships is limited. Meanwhile, the problem remains of finding the operating guide whose movements show most clearly the thrust of monetary actions on the economy. At present, there is no general agreement among monetary economists as to which measure best serves this purpose.

The Committee first selected required reserves as the operating guide and later switched to bank credit. Other aggregate measures frequently cited by monetary economists, including the money stock and the reserve base, were not used in the clause. This does not mean, however, that all other aggregate measures were ignored in the formulation of policy. Each member of the FOMC had a set of measures which he considered most important for monetary management and which influenced his evaluation of desired behavior for the operating guide actually selected.

An additional effect of the proviso clause is to permit the Committee to give instructions to the Desk that are applicable for slightly longer periods. The Committee is able to focas its attention more directly on

\footnotetext{
5The clause can have more than one provision for modifying market conditions as long as each provision is clearly defined and the various provisions are not inconsistent.
} 
economic developments and the proper growth in intermediate measures rather than on day-to-day fluctuations in market factors.

\section{Policy Changed More Continuously}

Changes in open market policy were called for on a more continuous basis in 1966 than in most previous years. The Committee tended to make more frequent and more gradual changes in its stated policy even though there was only one change in basic direction. In previous years, moves were often made in more discrete jumps. ${ }^{6}$

In the first half of the year, the Committee called for gradual moves toward more restraint. By the end of the year, the Committee directed gradual moves toward less restraint. Increasing emphasis was placed on the proviso clause following its introduction in May. Use of the clause, in itself, may reduce the need for more discrete policy changes in terms of money market conditions.

Treasury financing schedules were referred to in seven of the fifteen directives issued in 1966 (Exhibit I, Column 3). Movements in market interest rates indicate, however, that the traditional policy of maintaining an "even keel" during such finaneings may have been relaxed somewhat. During the February refunding and prefunding operations, interest rates rose sharply. Market conditions became firmer in May, and interest rates moved higher immediately prior to the Treasury's refunding. Interest rates increased very rapidly after completion of the August Treasury financing. A slight increase in yields followed the early November refunding. In contrast to these experiences, many interest rates declined around the time of the Treasury refunding in Jamuary 1967.

Changes in market interest rates during these financings reflected market developments which were only partially offset by the System rather than policy actions. Prior to 1966 , little variation in rates occurred during such periods. Treasury financings were scheduled so frequently that they often presented a major obstacle to implementing policy changes. Even with moderate rate variations during its financings in 1966 , the Treasury was able to obtain the funds it needed and the market suffered no great adverse effects.

\section{Operating Instruments More Varied}

In response to a variety of special challenges during the year, adjustments were made in the types of transactions included in open market operations.

\footnotetext{
6 For example, the June 1965 issue of this Review identifies more distinct policy periods in 1964 .
}

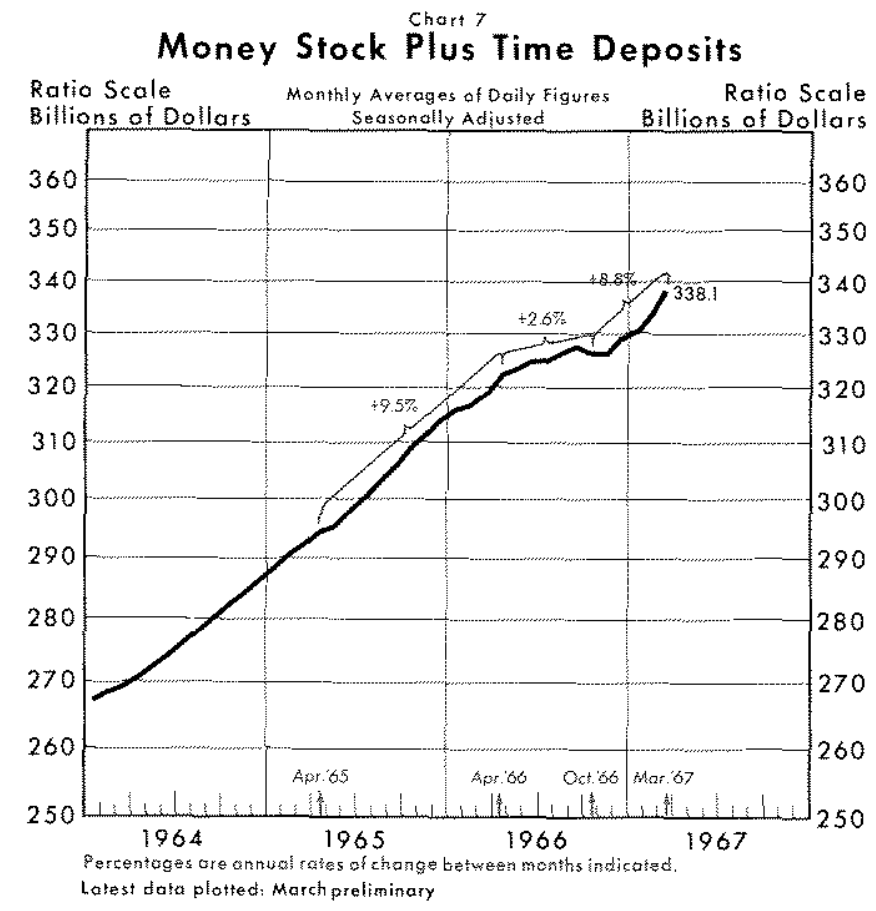

The simplest type of open market transaction is the outright purchase or sale of Government securities by the System. Another type of transaction is the repurchase agreement. In this case, the System buys Government securities from a dealer, agreeing to sell the same issues back at a specified price and within a specified time, not longer than fifteen days. In effect, the System supplies reserves to the banking system on a temporary basis. Since the dealers have the option of buying the securities back from the System before the agreement matures, the additional reserves are often withdrawn if other factors lead to increased reserve availability in the banking sector.

The Committee's continuing authority directive, which sets regulations for open market transactions, formerly restricted repurchase agreements under most circumstances to Government securities maturing within two years. On June 28 , the Committee voted to remove this restriction, giving the Desk authority to make repurchase agreements on other Treasury issues. This proved helpful at times when there was a scarcity of Treasury bills and other short-term Government securities in the market, such as in the late summer of last year.

The matched sale-purchase transaction was first used in July 1966. In this type of transaction, the System receives payment from the dealers for securities it sells temporarily, thereby absorbing reserves from the banking system. This technique was first used to offset large temporary increases in float (and in reserves) caused by the airline strike in July. Large outright 
sales of securities by the System at that time might have been misinterpreted as a move toward an even more stringent policy, and might have had undesired effects on market expectations.

Development of matched sale-purchase transactions along with the use of repurchase agreements facilitated the smoothing of market pressures. The Desk was able to provide or absorb reserves in substantial volumes for short periods more quickly and easily than formerly and with less effect on market expectations.

There was some concern in the third quarter of 1966 that even temporary fluctuations in market pressure would have significant-and undesirable-effects on market conditions and expectations. High interest rates and financing costs had led to a sharp curtailment of dealer inventories, making the market more sensitive to slight changes in the supply of or demand for securities. Repurchase agreements and matched sale-purchase transactions provided considerable flexibility for open market operations under these circumstances.

On November 1 , the Committee revised the continuing authority directive to enable the Desk to make repurchase agreements on securities that were direct obligations of or fully guaranteed by U. S. Government agencies. This action followed Congressional legislation making such securities eligible for purchase by the System. A few repurchase agreements involving agency securities were made after the authorization was given, but they represented only a small portion of total System repurchase agreements.

\section{Actions Complementing Open Market Operations}

Frequently during the year, the Federal Reserve used methods other than open market operations to implement monetary policy. Selective changes in System regulations, reserve requirements, and administration of the discount facilities were adopted in 1966.

\section{FEDRR RA}

\section{Date}

Announced June 27 (Effective July 14 for reserve sify bonks; July 21 for all other member bonks?

Announced July 15 (Effective July 20)

July 15

\section{Aug. 17}

[Effective Sept. 8 for reserve city bonks; Sept. 15 for all

other member bonks)

Sepl. 1

Announced Sept. 21

(Effective Sept. 26)

Dec. 27

Page 20
Description of Action

Differential reserve requirements established on time deposits. Requirements raised from 4 per cent to 5 per cent on each member bank's holdings of lime deposits (other than sovings deposits) in excess of $\$ 5$ mintion.

Maximum rale member bonks permitted to pay on fime deposits having multiple maturities lowered from $5 \frac{1}{2}$ per cent to 5 per cent on those of 90 doys or more and to 4 per cent on those of tess than 90 days.

Board of Governors requested broader authority from Congress for itselt, the Federal Deposit Insurance Corporation, and the Federal Home loon Bonk Boord in setting rate limitations for banks and savings and loan assoctations.

Differentid reserve requirements widened on time deposils. Requirements raised from 5 per cent to 6 per cent on each member bank's holdings of titme deposits lother than savings deposits) in excess of $\$ 5$ million.

Presidents of the Federal Reserve Banks sent a letter to ech member bank requesting maderation of business loan expansion and disposition of municipal securities. The lefter also stated, "It is recognized that banks odjusting their positions through foan curtailment may at times need a longer period of discount occommodation thon would be required for the disposition of securities."

Maximum rate member barks permitted to pay on any time deposit under $\$ 100,000$ reduced trom $\$ \frac{1}{2}$ per cent to 5 per cent. Simitar actions for instifutions under their furisdiction taken by Federal Deposit Insurance Corporation and Federal Home Loun Bank Board. Increased authority for establishing celling rates on fime deposits and on sovings accounts had been granted by Congress (see July 15 request for such legisletion?.

Seplember 1 letter rescinded because "tredit condifions have changed, the expansion of business loaris has been reduced to a thore moderate rote, and banks no longer are unlooding securities in unreceptive markets." Special discount arrangements mentioned in the original letfer were terminated.
Additional Information in the Federal Reserve Bulletin for:

July 1966 page 979

July 1966 , poges $979-980$

July 1966 . pages 979.980

Augusf 1966. page 1172

Seplember 1966. pages 1338.1339

Seplember $\$ 966$. page 1338

January 967 , poge 83 
Time Deposit Growth Restricted by Interest Rate Ceiling

The Board of Governors of the Federal Reserve System, through its Regulation Q, sets the maximum rates which member banks are allowed to pay on time and savings deposits. In previous years, the System had never used this power to affect very greatly the growth of time and savings deposits. Each time that rates reached the maximum, the maximum was raised. As noted earlier, the Board raised the maximum rate allowed on time deposits other than savings from $4: 2$ per cent to 5\% per cent in December 1965. In succeeding months, offering rates on time deposits rose rapidly. By summer, they reached the ceiling rate, and the regulation restricted time deposit growth. Thereafter, the only change in Regulation $Q$ was to lower the rate limit on certain types of time deposits (Exhibit II).

The Federal Reserve maintained the 5 per cent ceiling rate on time deposits even though yields on competitive market instruments and secondary market rates on certificates of deposit (CD's) rose substantially above this rate by the end of the summer. Com. mercial banks experienced a sharp net loss of large CD's after August. Total time deposits declined slightly from September to November. This loss of deposits can be attributed largely to the bite of Regulation $Q$. The effects of the regulation thus contributed to the slower growth of bank credit in the fall of 1966.

The economic impact of this action is less clear; presumably most savings continued to flow to investors through avenues other than commercial banks. As market rates rose above the maximum rates that commercial banks and other regulated intermediaries were allowed to pay on deposits, funds tended to flow directly into the financial markets rather than going through these intermediaries.

\section{Differential Reserve Requirements Established on Time Deposits}

In July 1966, for the first time, reserve requirements were established for one type of time deposits that were different than those for other types (Exhibit II). There is no clear-cut way to estimate the effect of these differential reserve requirements on economic stabilization. Higher costs may have made large banks somewhat less eager to seek time deposits. Also, these higher requirements absorbed some reserves, reducing the amount available to support demand deposits and bank credit unless offset by open market operations.

Possibly the major significance of these acts was that they indicated to the public the Federal Reserve's

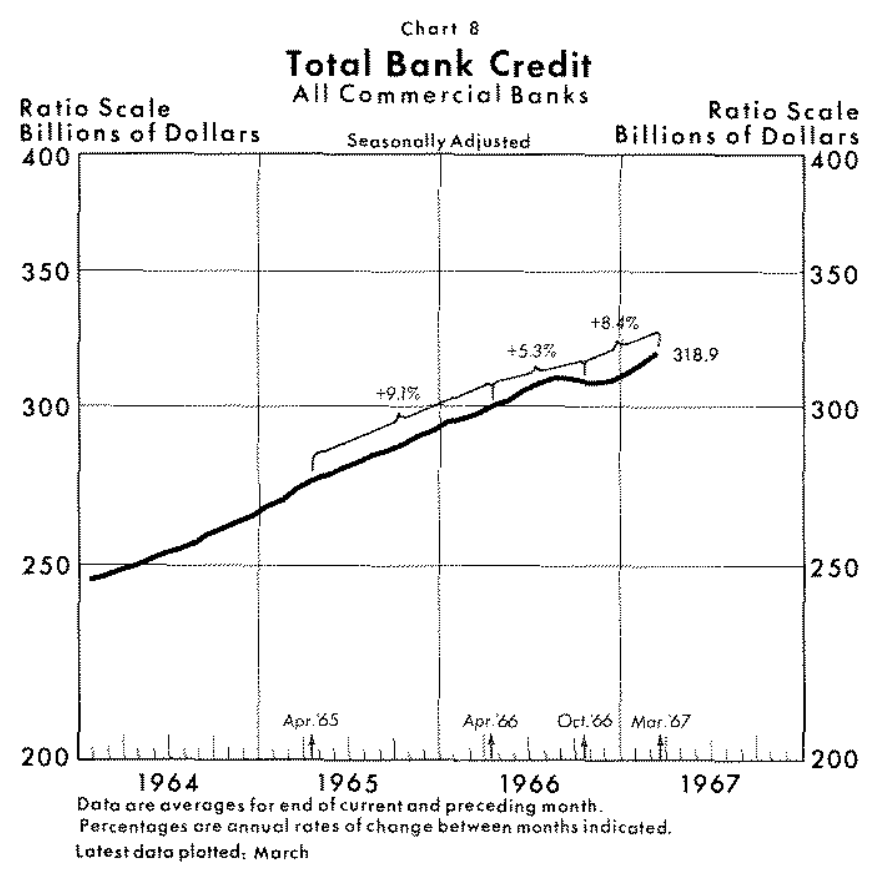

concern about the financial conditions then developing, particularly with regard to mortgage markets. The selective aspect of these changes, which excluded the first $\$ 5$ million of time deposits at each bank from the higher requirements, illustrated the Board's desire to moderate deposit expansion at the large banks without affecting smaller banks.

\section{Discount Rate Maintained Below Market Rates}

The absence of a change in the discount rate in the fall of 1966 was a marked departure from practices over the past few decades. It placed a greater burden on administration of the Reserve Banks discount windows. Throughout 1966, the discount rate remained at the $4: 2$ per cent level established in December 1965. This rate was clearly out of contact with market rates during most of the year (Chart 2). ${ }^{T}$ When this hap pened in the past, the discount rate was usually brought into line with market rates.

The Federal funds rate was almost continuously above the discount rate, with the margin increasing through late summer. From the viewpoint of an individual bank, buying Federal funds is a close substitute for borrowing from the Reserve Banks. Such transactions represent one member bank's making an overnight loan to another member bank.

Formerly, the market-determined rate on such transactions was near the administered discount rate, usu-

7 The directors of seven Reserve Banks did apply to the Board of Governors for permission to raise their discount rates, but no such permission was granted. 
ally below it. Banks would meet reserve deficiencies by borrowing Federal funds from other banks only if they could do so at or below the rate they would have to pay if they borrowed from their Reserve Bank. During 1965, the rate on Federal funds was frequently about $\%$ of a percentage point above the discount rate. The rate on Federal funds rose sharply during 1966 , while the discount rate remained unchanged. The Federal funds rate averaged 6 per cent during one week in early November, $11 \%$ percentage points above the discomt rate. The spreads between the Federal funds rate and the discount rate recorded in $1966 \mathrm{in}-$ dicate that member banks were reluctant to borrow too frequently from the Federal Reserve Bank, reflecting the rules of administration of this facility.

The September 1 letter sent by the Presidents of the Reserve Banks to each member bank in their district suggested closer administration of Federal. Reserve lending and moral suasion. The letter mentioned the availability of the discount window to member banks which cooperated in moderating their expansion of business loans and their disposition of some other assets.

This letter, which was in effect until late December, created much uncertainty in the banking system and in the financial markets. It represented a seldom used approach to administering the discount window. Suggestions by the lender of last resort are taken very seriously (sometimes even more seriously than intended) when the market is anticipating further reduction in the availability of funds. The volume of bank borrowing from the Federal Reserve Banks did not increase significantly, even though market rates were high relative to the discount rate. This suggests that some member banks mistakenly interpreted the letter as a threat to their use of the discount window.

Business loans, which had increased at an 18 per cent annual rate from mid-1965 to August 1966, grew at only a 6 per cent rate from August to December. This change of trend was probably due largely to the rapid decline of $\mathrm{CD}$ money during the period. There is thus some question as to how much of the moderation of growth in business loans was attributable to the September 1 letter. Business loans at large banks, for example, had declined for several weeks before the first letter was issued.

The 1966 experience demonstrated that the discount rate can be maintained at a rate substantially below market rates. Such conditions, however, require more discretionary administration of the discount window and provide subsidies to banks that do borrow. Limiting the desire to borrow through discount rate adjust- ments seems preferable from most points of view.

\section{Summary and Conclusions}

With the perspective of a few months, it appears that stated monetary policy during 1966 was generally appropriate under very challenging and rapidly changing economic conditions. At times during the year, the process of attaining policy objectives in terms of the aggregate monetary measures remained slow. From January to April, monetary expansion was excessive despite the stated policy of restraint. From May to October, aggregate measures generally moved more consistently with Committee desires. Toward the end of this period, the Committee apparently would have preferred some moderate expansion in these measures. In November and December, monetary expansion may have been weaker than desired. Monetary expansion did accelerate in early 1967, so the lag was moderate relative to most past experience. Progress was thus made in shortening the lag between policy decisions and changes in the aggregate measures.

During 1966, both new and seldom used techniques of monetary management were added to the more standard procedures to help achieve policy objectives. For example, innovations in the use of actions com. plementing open market operations allowed the System to exercise considerable restraint while maintaining orderly market conditions. Treasury financings apparently do not present as great an obstacle to policy changes as thought in many previous years. The moderate interest rate changes which occurred during the financings in 1966 had no great adverse effect on the market or on the Treasury's ability to secure funds. A wider variety of transactions available for open market operations also provided the System with greater operating flexibility.

To many economists, however, the most important new technique for monetary management was the proviso clause. After its adoption in May, the rates of monetary expansion appeared more in line with the Committee's desires than they had earlier in the year. But even with the proviso clause, there was a significant lag between the change in policy in late 1966 and the desired change in monetary expansion. FOMC directives at that time called for resumption of monetary growth. Money market conditions eased, but money and bank credit grew little from November to the end of the year.

Some time lag may be required for aggregate measures to respond to System actions. The wording of the clause in late 1966, however, may have added to 
the lag at that time. It called for a change in desired money market conditions only if monetary expansion proceeded too rapidly. In retrospect, the lag might have been shorter if the provision had been for greater easing of market conditions if bank credit expansion was not rapid enough.

The use of the proviso clause emphasizes the need for selecting the most useful operating guide for policy. It also emphasizes the need to understand more fully the relationships between money market conditions and the operating guide and among those aggregate monetary measures which might be used as operating guides. System research efforts in 1966 continued to be directed toward studying these linkages.

Questions might be raised about the use of bank credit as the intermediate guide, especially in view of the fluctuations in the rates of change in commercial bank intermediation. These fluctuations occurred chiefly because of changes in market rates relative to the Regulation $Q$ ceiling and probably had little effect on the total volume of credit available to borrowers. Deleting the reserve base and money supply as specified intermediate objectives may have been undesirable. There is considerable evidence that changes in these measures show more clearly the thrust of monetary actions on the economy.

The proviso clause places the Federal Reserve System, through its official policy actions, on record as recognizing that measures of money market concitions taken alone are not a sufficient guide even for short-run monetary management. Bank reserves, money, and bank credit have been the chief measures of monetary actions over periods of several months. Now their importance in analyzing week-to-week developments is becoming more apparent.

Elatne R, Goldstein

LeONALL C. ANDERSEN

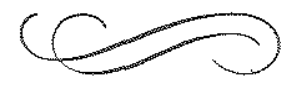

